This item was submitted to Loughborough's Research Repository by the author.

Items in Figshare are protected by copyright, with all rights reserved, unless otherwise indicated.

\title{
The distribution and biogeochemical importance of high-latitude dust in the Arctic and Southern Ocean-Antarctic regions
}

PLEASE CITE THE PUBLISHED VERSION

http://dx.doi.org/10.1002/2016JD026363

\section{PUBLISHER}

(C) American Geophysical Union (AGU)

\section{VERSION}

VoR (Version of Record)

\section{PUBLISHER STATEMENT}

This work is made available according to the conditions of the Creative Commons Attribution-NonCommercialNoDerivatives 4.0 International (CC BY-NC-ND 4.0) licence. Full details of this licence are available at: https://creativecommons.org/licenses/by-nc-nd/4.0/

\section{LICENCE}

CC BY-NC-ND 4.0

\section{REPOSITORY RECORD}

Bullard, Joanna E.. 2019. "The Distribution and Biogeochemical Importance of High-latitude Dust in the Arctic and Southern Ocean-antarctic Regions". figshare. https://hdl.handle.net/2134/24362. 


\section{Journal of Geophysical Research: Atmospheres}

\section{COMMENTARY}

10.1002/2016JD026363

Key Points:

- Dust from high-latitude sources can affect marine and terrestrial environments in polar regions

- High-latitude dust is typically transported and deposited at low altitudes

- Dust transport plays an important role in nutrient redistribution at high latitudes

Correspondence to:

J. E. Bullard,

J.E.Bullard@lboro.ac.uk

\section{Citation:}

Bullard, J. E. (2017), The distribution and biogeochemical importance of highlatitude dust in the Arctic and Southern Ocean-Antarctic regions, J. Geophys. Res. Atmos., 122, doi:10.1002/2016JD026363.

Received 9 DEC 2016 Accepted 6 FEB 2017

Accepted article online 19 FEB 2017
@2017. American Geophysical Union. All Rights Reserved.

\section{The distribution and biogeochemical importance of high- latitude dust in the Arctic and Southern Ocean- Antarctic regions}

\author{
Joanna E. Bullard ${ }^{1}$ \\ 'Department of Geography, Loughborough University, Loughborough, UK
}

\section{Introduction}

Over the past 30 years there has been an increased awareness of the significance of mineral dust in the Earth system. Mineral dust plays an important role in linking processes operating within the lithosphere, atmosphere, cryosphere, and oceans, transporting nutrients and sediments among systems and influencing the carbon, energy, and hydrological cycles [Ridgwell, 2002; Shao et al., 2011]. Increasingly sophisticated modeled estimates suggest total global dust emissions in the range $1000-4000 \mathrm{Tg} \mathrm{yr}^{-1}$ but converging around $2000 \mathrm{Tg} \mathrm{yr}^{-1}$. However, only dust sources in the low to middle latitudes have been well mapped (typically $<50^{\circ} \mathrm{N}$ and $<55^{\circ} \mathrm{S}$ ) [e.g., Ginoux et al., 2012], and there is mounting evidence to suggest that dust sources outside this zone are important and have been underappreciated in terms of their quantity and impact within and beyond the Arctic and Southern Ocean-Antarctica.

The occurrence of dust storms at high latitudes $\left(\geq 50^{\circ} \mathrm{N}\right.$ and $\left.\geq 40^{\circ} \mathrm{S}\right)$ has been recorded in expedition reports and research papers for over a century [e.g., Abercrombie, 1900]. These records highlight the importance of glacial processes, past and present, in supplying dust-sized sediments $(<100 \mu \mathrm{m})$ and conditioning landscapes for aeolian deflation. Until very recently sources of high-latitude dust have largely been considered in isolation and limited to specific regional areas such as Iceland [Arnalds et al., 2016, and references therein] and Patagonia [Gassó et al., 2010]. There was no real attempt to evaluate the overall importance of highlatitude dust sources in the global dust budget or of how changes in high-latitude environments responding to glacier retreat, carbon dioxide fertilization, and permafrost melt may alter the quantity, frequency, and intensity of dust emission and its impacts in the near and more distant future.

Within the past 5 years researchers have begun to try and understand the broader influence of contemporary dust emissions from high latitudes in two significant ways. The first is taking a hemispherical or global approach that makes it possible to consider the relative contribution and impact of high-latitude dust sources compared with those at lower latitudes. The second is by starting to describe the importance of aeolian processes in the facilitation of biogeochemical interactions and transfers of nutrients and sediments between system components in specific paraglacial landscapes, and into polar marine environments.

\section{Regional and Global Dust Emissions From High Latitudes}

Two recent studies have attempted to quantify the amount of dust contributed to the global dust budget from sources within the high latitudes. Groot Zwaaftink et al. [2016] used the Lagrangian particle dispersion model FLEXPART [Stohl et al., 1998] to model the quantity and dispersion of dust generated from within the Arctic region. FLEXPART has been widely used to provide insight into particle dispersion patterns worldwide and has been applied at high latitudes to individual dust events [Blechschmidt et al., 2012] and the 
resuspension of volcanic ash [Thorsteinsson et al., 2012] in Iceland. Groot Zwaaftink et al. [2016] suggest that from 2010 to 2012 dust emissions from land north of $60^{\circ} \mathrm{N}$ accounted for $1.7-5.3 \%$ of global dust emissions (averaging $48 \mathrm{Tg} \mathrm{yr}^{-1}$ ). Bullard et al. [2016] took a different approach, compiling field and remote sensing data from seven known contemporary high-latitude dust source regions (Alaska, Canada, Greenland, Iceland, Antarctica, New Zealand, and Patagonia) to estimate their contribution to the global cycle. Of the regions considered by Bullard et al. [2016], emissions data were only available for Alaska, Iceland, and Patagonia but suggest that at least $80-100 \mathrm{Tg} \mathrm{yr}^{-1}$ (approximately $5 \%$ of the global dust budget) originates from these three areas with 2-3\% associated with each hemisphere. Considering the contrasting approaches taken, Groot Zwaaftink et al. [2016] and Bullard et al. [2016] have produced remarkably similar estimates of highlatitude dust source contributions to the Northern Hemisphere. Both groups suggest that the amount of dust originating at high latitudes (both hemispheres) is similar to the proportion that originates from the U.S. (excluding Alaska) or Australia. A key difference between the two studies is the inclusion or otherwise of Eurasian dust sources. Bullard et al. [2016] found very little field evidence to suggest substantial dust emissions from this region, although local aeolian reworking of soils may take place, but using the FLEXPART model, Groot Zwaaftink et al. [2016] estimated mean annual high-latitude dust emission from Eurasia to be the same order of magnitude as that from North America (north of $60^{\circ} \mathrm{N}$ ). It is likely that relative dust emissions from North America and Eurasia have been overestimated in the FLEXPART model. Both groups of researchers suggest that they have underestimated the total contribution of all high-latitude dust sources due to uncertainties in the data sets used and a lack of dust concentration observations.

The total quantity of dust being produced at high latitudes is of interest, but so too is its dispersion. Whether the dust remains at high latitudes or is transported toward, the equator determines where it is deposited and subsequent impacts. Groot Zwaaftink et al. [2016] suggest that dust originating at latitudes $>60^{\circ} \mathrm{N}$ accounts for $27 \%$ of the total atmospheric dust load in the Arctic, with $38 \%$ being transported to the region from Asia and a farther 32\% from Africa. Using air parcel trajectory modeling of atmospheric transport pathways, Neff and Bertler [2015] concluded that the high-latitude dust sources in New Zealand and Patagonia were more likely to contribute dust to the Southern Ocean and Antarctica than sources in subtropical southern Africa or Australia. An important result of Neff and Bertler's [2015] study concerns the potential vertical profile of dust in the atmosphere. They found the vast majority of air parcels from New Zealand and Patagonia remain below about $2000 \mathrm{~m}$ above sea level $(800 \mathrm{hPa})$ even after 5 days in transport. A substantially higher proportion of air parcels from southern Africa and Australia reaches higher altitudes. This is likely to be due to the limited convection at higher latitudes that reduces vertical mixing and is also highlighted by Baddock et al. [2017] who explored transport pathways of dust from Iceland. The vertical development of dust plumes from Iceland is also limited, and Baddock et al. [2017] suggest that one result of this is that although Icelandic dust will cross the North Atlantic to east Greenland, it will rarely ascend high enough to reach the central part of the Greenland Ice Sheet. Groot Zwaaftink et al. [2016] explored the implications of high-latitude dust being restricted to low altitudes for spatial patterns of dust deposition. They found that $85 \%$ of dust at $<100 \mathrm{~m}$ altitude in the near-Arctic (north of $60^{\circ} \mathrm{N}$ ) was from high-latitude sources, with Asian and African dust contributing $9 \%$ and $5 \%$, respectively. With increasing altitude remote (non-Arctic) dust sources became more important. For example, in Greenland the model indicated that overall $67 \%$ of dust is of local origin, but at high altitudes this contribution drops to $<15 \%$ as dust transported from Africa and Asia becomes relatively more important.

The studies highlighted above have all used different approaches to investigate regional and global characteristics of high-latitude dust and are not strictly comparable; however, they can be used to provide some insight into the likely geographical area of influence of the dust. Figure 1 draws their conclusions together to suggest the main zones within the Arctic and Southern Ocean-Antarctica that are likely to be influenced by dust generated from different source areas within the high latitudes. Dust emissions from sources in Eurasia (north of $60^{\circ} \mathrm{N}$ ) influence a large area of the eastern Arctic, while those from North America influence the western Arctic. Iceland is the main contributor of dust to the North Atlantic Ocean, and the influence of Greenland dust is largely local to its coastline and the margins of the Greenland Ice Sheet. In the Southern Hemisphere dust emissions from Patagonia primarily affect the southern Atlantic and western part of the Southern Ocean while that from New Zealand influences the southern Pacific Ocean. Antarctica is not included in Figure 1 due to the limited amount of data available. The few existing studies suggest that the distribution of Antarctic-derived dust is restricted to the local coastline and inshore waters [Chewings et al., 2014; Winton et al., 2014] with some material transport onto the ice sheet [Delmonte et al., 2010]. 
a)

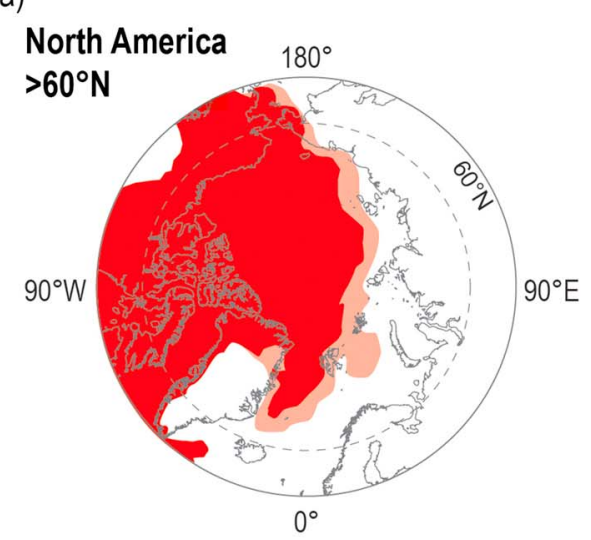

c)

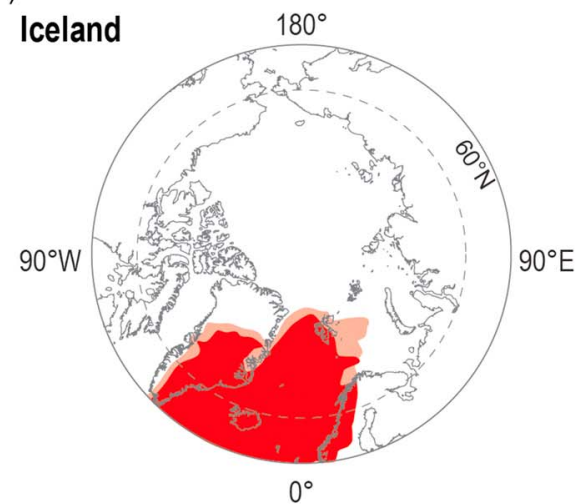

e)

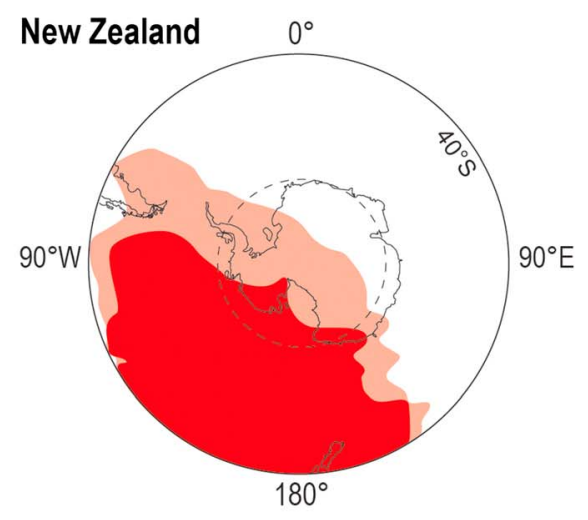

b)

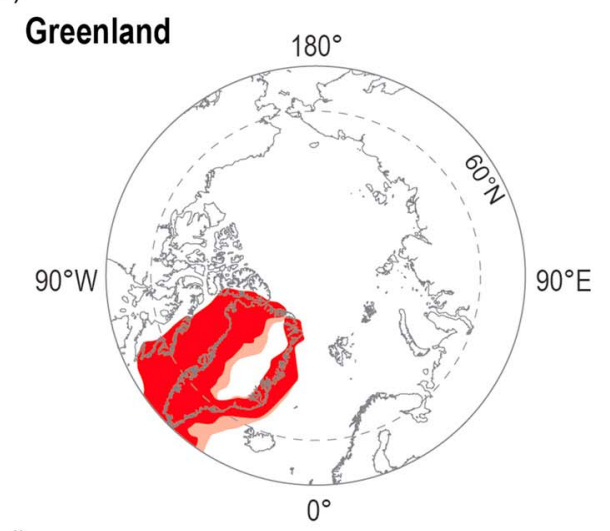

d)

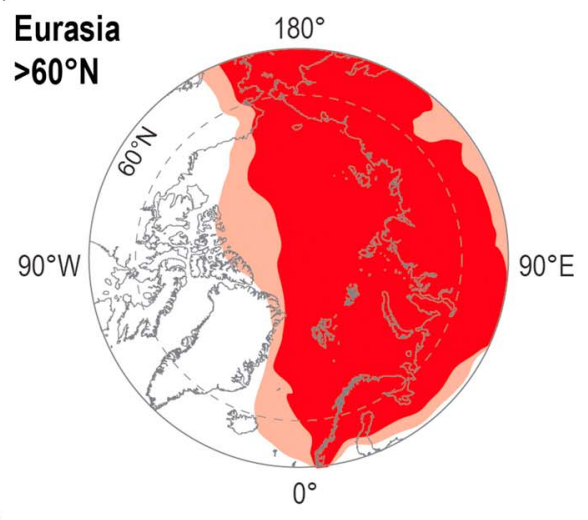

f)

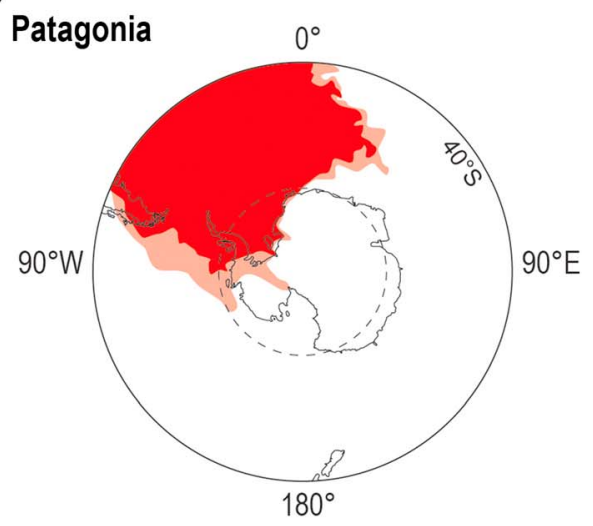

Figure 1. Potential geographical areas of influence of contemporary high-latitude dust sources from (a) North America, north of $60^{\circ} \mathrm{N}$; (b) Greenland; (c) Iceland; (d) Eurasia, north of $60^{\circ} \mathrm{N}$; (e) New Zealand; and (f) Patagonia (southern South America). See text for discussion.

\section{Dust Linkages in Paraglacial Landscapes}

Dust transport pathways are widely recognized as providing important linkages between different process domains [Ridgwell, 2002]. At a global scale around $20 \mathrm{Tg}$ dust are present in the atmosphere, and annually, approximately $2000 \mathrm{Tg}$ dust is deflated from the Earth's land masses of which $500 \mathrm{Tg} \mathrm{yr}^{-1}$ is deposited in the oceans and $1500 \mathrm{Tg} \mathrm{yr}^{-1}$ on land [Shao et al., 2011]. Most dust is deposited close to source, but some is transported substantial distances from continent to continent. At a local scale, the transport of dust within a landscape can be an important mechanism for transferring nutrients and sediments from one domain to another and the seasonality of emissions can determine the effect of these transfers. There have been recent attempts to determine the relative importance of dust emitted from individual sources (such as floodplains 


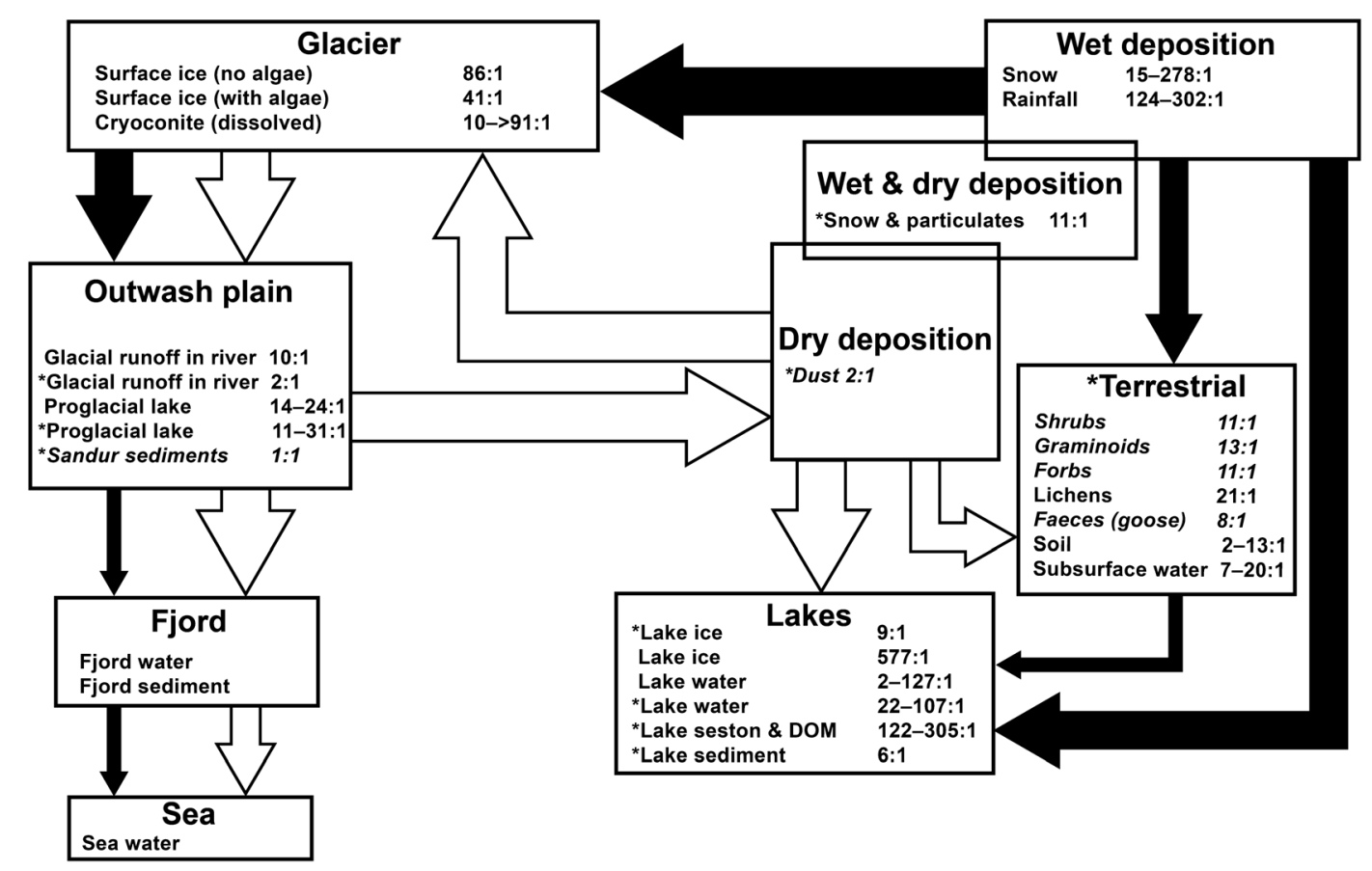

Figure 2. Cross-system transfers of nitrogen (black arrows) and phosphorus (white arrows) among components of the Kangerlussuaq. Arrow thickness indicates the degree of influence the transfer has on N:P ratios of the receiving system. Compiled from a range of sources by Anderson et al. [2017].

and loess deposits) or input to specific sinks (such as lakes, soils, and oceans) for biogeochemical cycling compared with inputs from hydrological sources.

Anderson et al. [2017] focus on the area $\left(6000 \mathrm{~km}^{2}\right)$ around Kangerlussuaq, west Greenland, which extends from the Greenland Ice Sheet to the Labrador Sea encompassing glacial outwash plains, moraines, a range of terrestrial ecosystems, and $>20,000$ lakes. They argue that despite the substantial meltwater discharge from the Greenland Ice Sheet, there is a hydrological disconnect between the ice sheet and adjacent terrestrial ecosystems due to topography and limited hydrological connectivity between the tundra soils and aquatic ecosystems due to low annual precipitation and the presence of continuous permafrost. They highlight the importance of aeolian processes for transporting nutrients and sediments between landscape components and the potential consequences for nutrient stoichiometry (Figure 2). In particular, Anderson et al. [2017] argue that because phosphorus adsorbs to sediments and particles, dust deposition contributes to $\mathrm{P}$ enrichment in catchments and can be a key nutrient subsidy to oligotrophic (nutrient-poor) lakes. The impact of dust is likely to be determined by not only the amount deposited but also the timing. For example, an accumulation of dust in ice and snow that is released upon melting as a single nutrient-rich pulsed input to a lake is likely to have a different effect on biogeochemical cycling compared with continuous lowmagnitude, high-frequency dust inputs to the lake surface throughout ice-free months. Aeolian deposition of locally derived organic and inorganic material is also increasingly recognized for its affects on snow and ice albedo and the formation of cryconite which in turn influence glacier and ice sheet hydrology and mass balance [Cooke et al., 2016].

Recent work on the input of terrestrial-derived nutrients to the Gulf of Alaska suggests that the soluble iron flux from dust originating in glaciofluvial sediment deposits from the entire Gulf of Alaska coastline is comparable to the annual Fe flux to Gulf of Alaska waters from eddies of coastal origin [Crusius et al., 2011]; however, the relative impacts of iron introduced to the ocean via these two mechanisms are still being investigated. Quantifying iron removal in the meltwater-dominated estuary of the Copper River, Gulf of Alaska, Schroth et al. [2014] found that $85 \%$ of dissolved Fe is removed in the low salinity region of the estuary, along with $41 \%$ of total dissolvable iron associated with fine glacial sediment, due to flocculation at the freshwater/saltwater mixing zone. The iron that does enter the ocean can be transported offshore to 
contribute to nutrient dynamics in Fe-limited phytoplankton populations. The large dust storms (e.g., 25$80 \mathrm{kt}$ in a single event) generated from braided river systems in the Copper River valley transport iron-rich sediments hundreds of kilometers over the ocean, but as yet there is insufficient evidence that these dust inputs lead directly to phytoplankton blooms. The dust storms occur occasionally throughout the year but are most prolific during the autumn and therefore deposit dust on the ocean surface at a time when light levels are low, restricting phytoplankton response. These sediments may possibly remain in solution near the ocean surface long enough to support phytoplankton blooms in the spring when conditions improve, but even if they do not, there is no doubt that aeolian transport of dust is an important contributor to total bioavailable iron in the Gulf of Alaska.

The relative importance of different sources of dissolved iron to surface waters has also been explored for Antarctic marine ecosystems. McGillicuddy et al. [2015] suggest that the largest sources of dissolved iron to the euphotic zone are wintertime mixing and melting sea ice. Locally derived aeolian contributions of dissolved iron can be either direct to the ocean or indirect, having first been deposited on sea ice or snow that subsequently melts, and are likely only to be a minor component of seasonal iron supply [Edwards and Sedwick, 2001; Winton et al., 2014].

These recent developments in research point to yet more need to better understand and quantify the sources, distribution, and impacts of dust from high-latitude sources. The recently compiled High Latitude and Cold Climate Dust Database (www.hlccd.org/database/) is an evolving resource that details publications that report research on this topic. The lack of entries in the database relating to Eurasian high-latitude dust sources highlights that these are poorly understood in terms of geographical distribution and importance and need to be better evaluated. There is a bigger picture requirement to start systematically including the high latitudes in "global" dust models to ensure that dust emissions from these regions are included in the estimates of global dust budgets. There are many challenges associated with this that include developing ways to accurately model wind regimes important for high-latitude dust emissions, such as katabatic and topographically driven winds, and the need to better understand the spatial distribution and temporal dynamics of high-latitude dust sources.

\section{Acknowledgments}

This research was part-funded by a Leverhulme Trust International Network grant (IN-2013-036). The author would like to thank Mark Szegner for his assistance with the figures and Cliff Atkins for his constructive comments on the paper.

\section{References}

Abercrombie, W. R. (Ed.) (1900), W.R. Abercrombie's Copper River Exploring Expedition, 1899, vol. 306, 450 pp., Government Printing Office, Washington.

Anderson, N. J., et al. (2017), The Arctic in the 21st century: Changing biogeochemical linkages across a paraglacial landscape of Greenland, BioScience, doi:10.1093/biosci/biw158.

Arnalds, O., P. Dagsson-Waldhauserova, and H. Olafsson (2016), The Icelandic volcanic aeolian environment: Processes and impacts-A review, Aeolian Res., 20, 176-195.

Baddock, M. C., T. Mockford, J. E. Bullard, and T. Thorsteinsson (2017), Pathways of high-latitude dust in the North Atlantic, Earth Planet. Sci. Lett., doi:10.1016/j.epsl.2016.11.034.

Blechschmidt, A.-M., J. E. Kristjánsson, H. Ólafsson, J. F. Burkhart, Ø. Hodnebrog, and P. D. Rosenberg (2012), Aircraft-based observations and high-resolution simulations of an Icelandic dust storm, Atmos. Chem. Phys., 12, 10,649-10,666, doi:10.5194/acp-12-10649-2012.

Bullard, J. E., et al. (2016), High-latitude dust in the Earth system, Rev. Geophys., 54, 447-485, doi:10.1002/2016RG000518.

Chewings, J. M. C., C. B. Atkins, G. B. Dunbar, and N. R. Golledge (2014), Aeolian sediment transport and deposition in a modern high latitude glacial marine environment, Sedimentology, 61, 1535-1557, doi:10.1111/sed.12108.

Cooke, J., A. Edwards, N. Takeuchi, and T. Irvine-Fynn (2016), Cryoconite: The dark biological secret of the cryosphere, Prog. Phys. Geogr., 40, 66-111, doi:10.1177/0309133315616574.

Crusius, J., A. W. Schroth, S. Gassó, C. M. Moy, R. C. Levy, and M. Gatica (2011), Glacial flour dust storms in the Gulf of Alaska: Hydrologic and meteorological controls and their importance as a source of bioavailable iron, Geophys. Res. Lett., 38, L06603, doi:10.1029/2010GL046573.

Delmonte, B., et al. (2010), Aeolian dust in the Talos Dome ice core (East Antarctica, Pacific/Ross Sea sector): Victoria Land versus remote sources over the last two climate cycles, J. Quat. Sci., 25, 1327-1337, doi:10.1002/jqs.1418.

Edwards, R., and P. Sedwick (2001), Iron in East Antarctic snow: Implications for atmospheric iron deposition and algal production in Antarctic waters, Geophys. Res. Lett., 28(20), 3907-3910, doi:10.1029/2001GL012867.

Gassó, S., A. Stein, F. Marino, E. Castellano, R. Udisti, and J. Ceratto (2010), A combined observational and modelling approach to study modern dust from the Patagonia desert to East Antarctica, Atmos. Chem. Phys., 10, 8287-8303, doi:10.5194/acp-10-8287-2010.

Ginoux, P., J. M. Prospero, T. E. Gill, N. C. Hsu, and M. Zhao (2012), Global-scale attribution of anthropogenic and natural dust sources and their emission rates based on MODIS Deep Blue aerosol products, Rev. Geophys., 50, RG3005, doi:10.1029/2012RG000388.

Groot Zwaaftink, C. D., H. Grythe, H. Skov, and A. Stohl (2016), Substantial contribution of northern high-latitude sources to mineral dust in the Arctic, J. Geophys. Res. Atmos., 121, 13,678-13,697, doi:10.1002/2016JD025482.

McGillicuddy, D. J., Jr., et al. (2015), Iron supply and demand in an Antarctic shelf ecosystem, Geophys. Res. Lett., 42, 8088-8097, doi:10.1002/ 2015 GL065727.

Neff, P. D., and N. A. N. Bertler (2015), Trajectory modelling of modern dust transport to the Southern Ocean and Antarctica, J. Geophys. Res. Atmos., 120, 9303-9322, doi:10.1002/2015JD023304.

Ridgwell, A. J. (2002), Dust in the Earth system: The biogeochemical linking of land, air and sea, Philos. Trans. R. Soc. London, 360, 2905-2924, doi:10.1098/rsta.2002.1096. 
Schroth, A. W., J. Crusius, I. Hoyer, and R. C. Campbell (2014), Estuarine removal of glacial iron and implications for iron fluxes to the ocean, Geophys. Res. Lett., 41, 3951-3958, doi:10.1002/2014GL060199.

Shao, Y., K.-H. Wyrwoll, A. Chappell, J. Huang, Z. Lin, G. H. McTainsh, M. Mikami, T. Y. Tanaka, X. Wang, and S. Yoon (2011), Dust cycle: An emerging core theme in Earth system science, Aeolian Res., 2, 181-204.

Stohl, A., M. Hittenberger, and G. Wotawa (1998), Validation of the lagrangian particle dispersion model FLEXPART against large-scale tracer experiment data, Atmos. Environ., 32(24), 4245-4264, doi:10.1016/S1352-2310(98)00184-8.

Thorsteinsson, T., T. Jóhannsson, A. Stohl, and N. I. Kristiansen (2012), High levels of particulate matter in Iceland due to direct ash emissions by the Eyjafjallajökull eruption and resuspension of deposited ash, J. Geophys. Res., 117, B00C05, doi:10.1029/2011JB008756.

Winton, V. H. L., G. B. Dunbar, N. A. N. Bertler, M.-A. Millet, B. Delmonte, C. B. Atkins, J. M. Chewings, and P. Andersson (2014), The contribution of aeolian sand and dust to iron fertilization of phytoplankton blooms in southwestern Ross Sea, Antarctica, Global Biogeochem. Cycles, 28, 423-436, doi:10.1002/2013GB004574. 